\title{
Lymnaea palustris and Lymnaea fuscus are potential but uncommon intermediate hosts of Fasciola hepatica in Sweden
}

Adam Novobilský1* ${ }^{*}$, Martin Kašný ${ }^{2,3}$, Luboš Beran $^{4}$, Daniel Rondelaud ${ }^{5}$ and Johan Höglund ${ }^{1}$

\begin{abstract}
Background: Lymnaea palustris and L. fuscus are members of the European stagnicolines (Gastropoda: Lymnaeidae). The role of stagnicolines in transmission of Fasciola hepatica has been often proposed. To assess the possible relationship between these two stagnicolines and F. hepatica in Sweden, field monitoring in parallel with experimental infections of $L$. palustris and $L$. fuscus were conducted.

Methods: Stagnicoline snails were collected and identified on pastures grazed by either sheep or cattle on four farms suffering from fasciolosis in Sweden during 2011-2012. Field-collected L. palustris and L. fuscus were examined for F. hepatica DNA by PCR. In the laboratory, different age groups of L. palustris, L. fuscus and G. truncatula were each exposed to two $F$. hepatica miracidia and main infection characteristics were obtained.

Results: One field-collected L. palustris (out of $n=668$ ) contained $F$. hepatica as determined by PCR. On the other hand, stagnicolines artificially exposed to $F$. hepatica miracidia resulted in successful infection with fully differentiated cercariae, but only in juvenile snails (size, $1-2 \mathrm{~mm}$ at exposure) and with a prevalence of $51 \%$ and $13 \%$ in L. palustris and L. fuscus, respectively. In contrast, $90 \%$ of juvenile (size, $1-2 \mathrm{~mm}$ ) and $92 \%$ of preadult $G$. truncatula (size, $\geq 2-4 \mathrm{~mm}$ ), respectively, were successfully infected. Delayed, reduced and/or no spontaneous cercarial shedding was observed in the two stagnicolines when compared to G. truncatula. However, at snail dissection most cercariae from L. fuscus and L. palustris were able to encyst similarly to those from G. truncatula.

Conclusion: Both L. fuscus and L. palustris can sustain larval development of $F$. hepatica but with an apparent level of age resistance. The finding of a single $F$. hepatica positive specimen of $L$. palustris, together with infection characteristics from the experimental infection, suggest that $L$. palustris is a more suitable snail vector of $F$. hepatica than L. fuscus. The reduced growth observed in both stagnicolines was contrary to the 'parasitic gigantism' theory. Overall, it seems that the epidemiological role of L. palustris in transmission of F. hepatica in Sweden is likely to be much lower than for $G$. truncatula.
\end{abstract}

Keywords: Fasciola hepatica, Fascioloides, Galba truncatula, Intermediate host, ITS-2, Lymnaea fuscus, Lymnaea palustris, Lymnaeidae, Metacercariae, Shell size

\footnotetext{
* Correspondence: anovobilsky@yahoo.com

'Department of Biomedical Sciences and Veterinary Public Health, Section for

Parasitology, Swedish University of Agricultural Sciences (SLU), Uppsala 750

07, Sweden

Full list of author information is available at the end of the article
}

\section{Biomed Central}

(c) 2013 Novobilský et al.; licensee BioMed Central Ltd. This is an Open Access article distributed under the terms of the Creative Commons Attribution License (http://creativecommons.org/licenses/by/2.0), which permits unrestricted use, distribution, and reproduction in any medium, provided the original work is properly cited. 


\section{Background}

The liver fluke Fasciola hepatica is a worldwide distributed generalistic parasite with a di-heteroxenous life cycle including both mammalian (mainly ruminants) and certain gastropod hosts [1]. Several snail species within the family Lymnaeidae play an essential role as intermediate hosts for this digenean. In Europe, Galba truncatula is considered to be the principal intermediate host of F. hepatica in most environments [2]. However, in some locations it has been shown that that it can be replaced by other taxonomically related snails, such as Omphiscola glabra [3] and Radix spp. [4,5]. Although G. truncatula is considered the main intermediate host of F. hepatica in Scandinavia, this has so far been confirmed only in Denmark [6].

The phylogeny and generic classification of the family Lymnaeidae is a problematic issue, with divergent conclusions between studies [7]. A morphologically similar group of snails within the family Lymnaeidae, commonly known as stagnicolines [8], has been suggested to be potentially susceptible to F. hepatica [9-11]. According to recent phylogenetic studies, there is evidence for a clear genetic variability between European and North American stagnicolines. Five formerly recognized European stagnicolines (Stagnicola palustris, S. turricula, S. fuscus, S. corvus, $S$. occulta) $[12,13]$ have all recently been reclassified $[10,11]$ into four taxa as follows: Lymnaea palustris (formerly S. palustris and S. turricula), L. fuscus, L. corvus, Catascopia terebra (formerly S. occulta) [10,14,15]. All of these stagnicoline species, except $C$. terebra, are present in Sweden, where they occur in marshland and/or near lakes, and often share habitat with G. truncatula [16,17]. It may be hypothesized that all stagnicoline snails are exposed to F. hepatica miracidia in habitats grazed by F. hepaticainfected ruminants, and along with G. truncatula they may serve equally well as intermediate hosts for the parasite. The infection of L. palustris and L. fuscus with F. hepatica miracidia has been completed under laboratory conditions $[18,19]$, but these data need to be further confirmed, especially due to the above-mentioned taxonomic problems within the family Lymnaeidae. Since knowledge about the infection status of European stagnicoline snails is limited, the main aim of this study was to determine the potential of $L$. palustris and L. fuscus as intermediate snail hosts in the transmission of F. hepatica.

\section{Methods}

\section{Detection of $F$. hepatica in field-collected snails} Study areas and snail collection

To screen for the potential vector capacity of stagnicolines in Sweden, snails collected on three beef cattle farms and one sheep farm were monitored during a two year period. During the first visits in May and June 2011, potential snail habitats were identified and a survey for infected snails was initiated. All four farms had a history with fasciolosis and prevalence in slaughtered animals exceeding 50\%. Snail habitats (sampling sites) at all three cattle farms were marshy coastal areas near freshwater lakes and were represented by a gradual transition between the lake and the grazing area. At the sheep farm (Lilla Edet), the snail habitats consisted of drainage ditches and creeks localized between improved pastures. Beside stagnicolines, G. truncatula was also present at all farms. While the habitats of stagnicolines and G. truncatula completely overlap, and snails were located in the mud (no water layer) at the three beef cattle farms, a biotope boundary line was apparent at Lilla Edet. Thus, stagnicoline populations at the three beef cattle farms possess a high level of amphibiousity, commonly known only for G. truncatula. In contrast, the habitat (deeper water bodies) of the stagnicoline population at Lilla Edet was similar to those described for Radix spp. or Lymnaea stagnalis [13].

Snail collection was always performed by the same person and in the same quadrates during all visits, at 20 min time intervals in accordance with a previous study [20]. After their collection, snails were placed in $0.1 \mathrm{~L}$ plastic containers with water and then transferred to the laboratory. Within 24 hours of collection, all snails were classified according to their shell morphology $[12,13]$ and individually frozen $\left(-20^{\circ} \mathrm{C}\right)$ in microfuge tubes for further examination.

\section{Morphological and molecular identification of snails}

Four to ten snails per population (farm), representing each ecotype and sharing the same shell morphology, were euthanized in hot water and placed in $70 \%$ ethanol for morphological determination of their genitalia. These snails were identified on the basis of the length of their reproductive organs and the shape of the bursa copulatrix according to taxonomic keys [12,13].

Furthermore, two additional snails per population showing the same morphology as mentioned above were selected for molecular identification. This was based on amplification and sequencing of the internal transcribed spacer 2 (ITS-2) region of the ribosomal DNA [11]. Briefly, genomic DNA was extracted from whole snail bodies (2 specimens per farm) using DNeasy Blood and Tissue Kit (Qiagen, Germany) according to the manufacturer's instructions. Polymerase chain reaction (PCR) amplification of snail ITS-2 was carried out with primers designed in a previous study [11] (forward: LT1 5' TCGTCTGTGTGAGGGTCG-3'; reverse: ITS-2 Rixo R: $5^{\prime}$-TTCTATGCTTAAATTCAGGGG-3'), in $25 \mu \mathrm{l}$ reaction tubes, as follows: $1 \mu \mathrm{l}$ of snail DNA, $10 \mathrm{mM}$ Tris- $\mathrm{HCl}$ $\mathrm{pH}$ 8.3, $50 \mathrm{mM} \mathrm{KCl}, 2 \mathrm{mM} \mathrm{MgCl}_{2}, 4 \mu \mathrm{g}$ Bovine Serum Albumin (BSA; New England Biolabs, Inc., UK), $0.8 \mu \mathrm{M}$ of each primer, $0.2 \mathrm{mM} \mathrm{dNTP}$ and $0.3 \mathrm{U}$ Taq polymerase (Ampli Taq Gold, Applied Biosystems, USA). Separation, 
purification and sequencing of the PCR products was carried as described earlier [21]. Sequences were edited with CLC Main Workbench (version 5.6.1), and compared with sequences available in GenBank (accessed in March 2013) [GenBank: AJ243017; AJ272051; AJ296271; AJ319620; AJ319621; AJ319622; AJ319623; AJ319624; FR797838; FR797839; FR797840; FR797841; FR797845; FR797846; FR797847; FR797848; HE577631; HE577632; HE577633; HE577634; HE577635; HE577636; HE577637; HE613327; JN614443; JN614444; JN614445; JN614446; JN614447; JN614448; JN614449], using Clustal W2 (EMBL-EBI) and the basic local alignment search (BLAST) tool (http:// blast.ncbi.nlm.nih.gov/).

\section{Monitoring of snail infection by $P C R$}

Field-collected snails (size range, $8-18 \mathrm{~mm}$ ) were thawed and examined by a PCR method designed to detect F. hepatica larval DNA as follows. Snails were examined as pooled samples (pooled after the lysis step of DNA extraction) that consist of 2-10 individual snails per sample. Whole snail bodies were individually crushed with sterile pestles and mechanically disrupted. Tissue was lysed in $20 \mu \mathrm{l}$ of proteinase $\mathrm{K}$ and $180 \mu \mathrm{l}$ lysis buffer (Qiagen, Germany) at $56^{\circ} \mathrm{C}$ overnight. After lysis, $20 \mu \mathrm{l}$ of each lysed individual were taken into a pooled sample. Genomic DNA was extracted from each pool using the DNeasy Blood and Tissue Kit as described earlier. Sensitivity of $F$. hepatica PCR was verified by prior testing of a pool containing the lysate from 9 uninfected snails and 1 experimentally infected snail. Extracted pooled snail DNA was then amplified by PCR using Ampli Taq Gold kit. F. hepatica specific primers (forward: FH-ITS2-SPEC-F 5' CTTATGATTTCTGGGATAATT-3', reverse: FH-ITS2SPEC-R 5'-CCGTCGCTATATGAAAA-3') described in [22] were used to amplify $112 \mathrm{bp}$ region of the F. hepatica ITS-2 gene. The PCR mixture was prepared in the identical proportions, as described earlier for PCR amplification of ITS-2. Amplifications were generated in a 2720 Thermal Cycler (Applied Biosystems, USA), by 40 cycles of $45 \mathrm{sec}$ at $95^{\circ} \mathrm{C}, 1 \mathrm{~min}$ at $55^{\circ} \mathrm{C}$ and $1 \mathrm{~min}$ at $72^{\circ} \mathrm{C}$, preceded by $10 \mathrm{~min}$ at $95^{\circ} \mathrm{C}$ and followed by $5 \mathrm{~min}$ at $72^{\circ} \mathrm{C}$. The amplification products were separated on $1.5 \%$ agarose gel stained with GelRed ${ }^{\mathrm{Tm}}$ Nucleic Acid Gel Stain (Biotium, USA). Whenever F. hepatica positive pools samples were identified all individuals in the same sample were re-tested according to the above mentioned PCR protocol. To eliminate any possible error of morphological species determination for any infected individual snails, their identity was also verified by sequencing as stated above.

The specificity of primers was evaluated by testing DNA samples originating from adult F. hepatica, adult Fascioloides magna, L. palustris experimentally infected with $F$. hepatica or F. magna and one specimen of G. truncatula naturally infected with Haplometra cylindracea. The specificity was compared with a previously described protocol $[5,23]$ based on amplifying of a specific fragment of the cytochrome $\mathrm{C}$ oxidase subunit 1 gene (cox-1) of F. hepatica.

\section{Experimental infections of snails Parasite}

Eggs of $F$. hepatica were isolated from bovine livers by washing bile ducts at an abattoir in Skövde (western Sweden). F. hepatica eggs were washed several times with physiological saline, and stored in a $0.3 \mathrm{~cm}$ tap water layer at $4^{\circ} \mathrm{C}$ in the dark until use. To initialize embryonation, suspended eggs were incubated for 15 days at $25^{\circ} \mathrm{C}$ in the dark. Hatching was stimulated by exposing the mature eggs to intensive light (approx. 4000 lux), and after $30 \mathrm{~min}$ miracidia attracted to the light source were collected.

\section{Snails exposed to miracidia}

To compare the susceptibility of stagnicoline species to $F$. hepatica and to characterize intramolluscan development of $F$. hepatica, different age and size groups of L. fuscus, L. palustris and G. truncatula (which was included as a susceptible reference) were exposed to F. hepatica miracidia. All three snail species were morphologically and molecularly identified to species as described above. In the case of L. fuscus and L. palustris, adult snails were collected from the field and then maintained in plastic containers in the laboratory for egg production. The F1 generations were hatched and then used for the study. The parent generations of the L. fuscus and L. palustris populations originated from Lilla Edet and Norrköping, respectively (Table 1). Specimens of G. truncatula were collected from a road ditch outside Uppsala, Sweden (coordinates: 59.88 N $17.58 \mathrm{E}$ ), and from an area where livestock and wildlife were excluded from grazing. A total of 200 juvenile G. truncatula (in the size range 1-4 mm) were collected and used in the experiment. Examination of $200 \mathrm{G}$. truncatula from the same site revealed no trematode infections. Snails of all three isolates were measured (Biltema digital caliper 16-105, Sweden; with an accuracy $0.03 \mathrm{~mm}$ ), and divided into 16 experimental groups as shown in Table 2.

\section{Experimental protocol}

Individual snails were exposed to 2 miracidia in a small volume $(300 \mu \mathrm{l})$ of artificial pond water (APW) dispensed into the wells of a 96-well plastic plate. Miracidia were added to each well, closed with conical caps, and incubated for 12 hours. Following miracidial exposure, all snails of the same species and the same group were transferred to a plastic box $(40 \times 30 \times 19 \mathrm{~cm})$ containing a $4 \mathrm{~cm}$ deep layer of APW, where they were maintained during the first 30 days post-exposure (PE). All boxes 
Table 1 Origin of snail populations collected from the field

\begin{tabular}{|c|c|c|c|c|c|}
\hline \multirow[b]{2}{*}{ Locality } & \multirow[b]{2}{*}{ Coordinates } & \multirow[b]{2}{*}{ Type of farm } & \multicolumn{2}{|c|}{ Number of collected snails } & \multirow[b]{2}{*}{ GenBank accession numbe } \\
\hline & & & $\begin{array}{c}\text { Lymnaea palustris } \\
\qquad \mathrm{n}=668\end{array}$ & $\begin{array}{l}\text { Lymnaea fuscus } \\
\qquad n=130\end{array}$ & \\
\hline Norrköping & $58.62 \mathrm{~N}, 16.38 \mathrm{E}$ & beef cattle & 323 & & 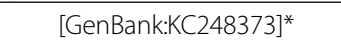 \\
\hline Linköping & $58.46 \mathrm{~N}, 15.56 \mathrm{E}$ & beef cattle & 245 & & [GenBank:KC248374] \\
\hline Kristianstad & $56.07 \mathrm{~N}, 14.11 \mathrm{E}$ & beef cattle & 100 & & [GenBank:KC905167] \\
\hline Lilla Edet & $58.09 \mathrm{~N}, 12.23 \mathrm{E}$ & sheep & & 130 & [GenBank:KC248371] ${ }^{* *}$ \\
\hline
\end{tabular}

* F1 generation of this L. palustris isolate was used in the experimental study.

** F1 generation of this $L$. fuscus isolate was used in the experimental study.

were placed in an air-conditioned room at $22^{\circ} \mathrm{C}$ and with a photoperiod including a 10 hours light cycle. During the experiment, snails were fed ad libitum with pesticide-free fresh lettuce, and the APW was changed weekly. After 30 days PE, each surviving snail was transferred to a $3.5 \mathrm{~cm}$ Petri dish and maintained according to the same conditions as during the first 30 days. Petri dishes were checked daily for cercariae and/or metacercariae under a stereomicroscope at a magnification of $15 \times$. Water was changed daily and $\approx 1 \mathrm{~cm}^{2}$ of decomposed lettuce was added. From day 50 PE for G. truncatula and day $60 \mathrm{PE}$ for L. fuscus and L. palustris, all surviving snails in both the exposed and non-exposed groups were subjected to thermal shock [24] every second day, by placing their Petri dishes at $10^{\circ} \mathrm{C}$ for 3 hours to stimulate cercarial emergence. At day $65 \mathrm{PE}$ for G. truncatula and at day $95 \mathrm{PE}$ for $L$. fuscus and L. palustris, surviving snails were measured with a digital caliper. Snails were then crushed and their soft tissues were individually transferred into new Petri dishes with fresh water for cercarial shedding. Encysted and non-encysted cercariae were counted 2 hours after crushing.

\section{Testing of in vitro excystment of $F$. hepatica} metacercariae

In vitro excystment was applied to test the viability and excystment ability [25] of $F$. hepatica metacercariae. These larvae were collected from all three snail species after shell crushing, and were maintained in water at $4^{\circ} \mathrm{C}$ in the dark for a maximum of one month. To remove the outer cyst a total of $\approx 100$ metacercariae per snail species were exposed to $1 \%$ sodium hypochlorite by

Table 2 Summary of snail species and groups used in the experimental study

\begin{tabular}{|c|c|c|c|c|c|c|}
\hline \multirow[b]{3}{*}{ Snail species } & \multicolumn{6}{|c|}{ Shell size at day of exposure } \\
\hline & $1-2 \mathrm{~mm}$ & $1-2 \mathrm{~mm}$ & $\geq 2-4 \mathrm{~mm}$ & $\geq 2-4 \mathrm{~mm}$ & $\geq 4-6 \mathrm{~mm}$ & $\geq 4-6 \mathrm{~mm}$ \\
\hline & \multicolumn{6}{|c|}{ Lymnaea fuscus } \\
\hline Number of snails at exposure & 100 & 50 & 100 & 50 & 100 & 50 \\
\hline Number of miracidia & 2 & - & 2 & - & 2 & - \\
\hline Survival rate at day 30 post-exposure (\%) & 69 & 90 & 79 & 86 & 100 & 100 \\
\hline $\begin{array}{l}\text { Mean shell height }( \pm S . D .) \text { of } C S+\text { NCS snails } \\
\text { at their death }(\mathrm{mm})\end{array}$ & $5.9 \pm 1.6$ & $11.2 \pm 0.9$ & $13.4 \pm 0.9$ & $13.8 \pm 0.8$ & $15.3 \pm 1.1$ & $15.1 \pm 0.8$ \\
\hline Snail species & \multicolumn{6}{|c|}{ Lymnaea palustris } \\
\hline Number of snails at exposure & 100 & 50 & 100 & 50 & 100 & 50 \\
\hline Number of miracidia & 2 & - & 2 & - & 2 & - \\
\hline Survival rate at day 30 post-exposure (\%) & 78 & 82 & 91 & 90 & 100 & 100 \\
\hline $\begin{array}{l}\text { Mean shell height }( \pm \text { S.D. }) \text { of } C S+\text { NCS snails } \\
\text { at their death }(\mathrm{mm})\end{array}$ & $6.8 \pm 2.2$ & $10.6 \pm 0.8$ & $12.9 \pm 1.6$ & $13.3 \pm 1.3$ & $14.1 \pm 1.3$ & $14.5 \pm 1.6$ \\
\hline Snail species & \multicolumn{6}{|c|}{ Galba truncatula } \\
\hline Number of snails at exposure & 100 & 50 & 100 & 50 & - & - \\
\hline Number of miracidia & 2 & - & 2 & - & - & - \\
\hline Survival rate at day 30 post-exposure (\%) & 57 & 66 & 74 & 88 & - & - \\
\hline $\begin{array}{l}\text { Mean shell height }( \pm \text { S.D. }) \text { of } C S+\text { NCS snails } \\
\text { at their death }(\mathrm{mm})\end{array}$ & $4.6 \pm 1.0$ & $4.5 \pm 1.1$ & $6.2 \pm 1.2$ & $5.8 \pm 1.0$ & - & - \\
\hline
\end{tabular}

Abbreviations.

CS cercariae shedding snails (spontaneous shedding of cercariae during experiment).

NCS non cercariae shedding snails (snails that did not produce cercariae spontaneously but contained $F$. hepatica larvae). 
adding $2 \mathrm{ml}$ of the salt solution to the microfuge tube for $20 \mathrm{~min}$ at $20^{\circ} \mathrm{C}$. After incubation, metacercariae were washed 3 times with pond water and once with Activating and Excysting Medium (AEM). AEM consisted of RPMI-1640 medium (Sigma-Aldrich, USA), 1\% antibiotic antimycotic solution (code A5955, Sigma-Aldrich, USA), $0.9 \%$ bovine bile (Oxoid, UK) and $0.006 \%$ L-cysteine (Sigma-Aldrich, USA). Metacercariae were then transferred into a 24 -well plate ( $1 \mathrm{ml}$ of AEM per well) and incubated at $38^{\circ} \mathrm{C}$ in the dark with a $\mathrm{CO}_{2}$ level of $20 \%$. After 4 hours, newly hatched juveniles and non-excysted metacercariae were counted at a magnification of $200 \times$ under a stereomicroscope with transmitted light. Each batch of metacercariae originating from L. fuscus, L. palustris, and/or G. truncatula was tested in triplicate.

\section{Data and statistical analyses}

In experimental infections, survival rate at day $30 \mathrm{PE}$ and the prevalence of $F$. hepatica infection in relation to the number of surviving snails at day $30 \mathrm{PE}$ were determined. The following characteristics were recorded: mean and total number of spontaneously emerged cercariae from cercariae-shedding (CS) snails; first day of cercarial shedding; mean number of metacercariae obtained from snails where no cercarial shedding (NCS) was observed until dissection; and shell size at the end of the experiment. All statistical analyses were performed using GraphPad Prism 5.02 (GraphPad Software, USA). Analysis of variance (ANOVA) was applied to assess differences between mean sizes of infected snails, exposed but uninfected snails, and the snails from the negative control group. ANOVA, followed by Bonferonni post-hoc tests, were also applied to compare differences in metacercarial production. Pearson correlation analysis was carried out to evaluate the relationship between shell size and cercarial production. All statistical tests were considered significant when $\mathrm{p} \leq 0.05$.

\section{Results}

\section{Snail identification}

The anatomical structure of the reproductive organs, especially the length of the preputium and the shape of the bursa copulatrix at section, in the stagnicoline isolate from Lilla Edet agreed with those already reported for Stagnicola fuscus [12,13]. Also, the ITS-2 sequence of the Lilla Edet isolate [GenBank: KC248371] had 98-99\% similarity to Lymnaea fuscus genotypes 1 and 2 [GenBank: AJ319622; AJ319621] and Stagnicola fuscus [GenBank: HE577637; HE613327; HE577636; HE577634; HE577633]. Furthermore, the snail isolates collected from Norrköping, Linköping and Kristianstad were morphologically identical to L. palustris $[12,26]$. Following a BLAST search of ITS-2, all three isolates [GenBank: KC248373; KC248374; KC905167] had 99\% similarity to L. palustris or L. turricula [GenBank: JN614468; AJ319620; AJ457043; HQ283267; AJ319618; AJ319619; HE577632; HE577631; FR797839; FR797838; FR797840; FR797841]. The sequence of the Uppsala isolate of G. truncatula [GenBank: KC248372] used in the experimental study had 100\% identity to French and Venezuelan isolates of G. truncatula [GenBank: JN614444; JN614445; JN614443] [10]. For quantitative proportion of collected snails see Table 1.

\section{Specificity of primers}

After PCR with ITS-2 region specific primers (described in [22]) and DNA isolated from adult F. hepatica and L. palustris snails (experimentally infected with $F$. hepatica) followed by agarose electrophoresis the 112 bp PCR product was recorded. No visible amplicons were observed after control PCR with DNA samples isolated from adult F. magna, neither snails infected with F. magna and/or H. cylindracea. In the PCR with cox-1 region specific primers (described in [23]), however, PCR products $(\approx 405 \mathrm{bp})$ for analyzed samples (DNA from F. hepatica, F. magna, L. palustris) were recorded (Figure 1).

\section{Monitoring of $F$. hepatica infection of snails collected in the field}

A total of 668 snails determined as L. palustris [GenBank: KC248373; KC248374; KC905167] from all three sampling sites (Norrköping, Linköping and Kristianstad) during 2011-2012 were examined for liver fluke DNA by PCR. Only one L. palustris collected on the beef farm in Linköping was $F$. hepatica positive. The species identity of

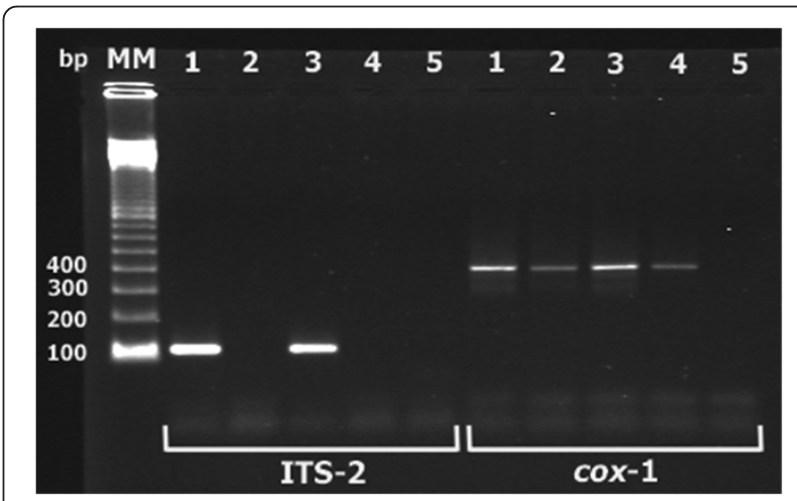

Figure 1 Agarose gel electrophoresis of amplified ITS-2 and cox-1; evaluation of the specificity of our PCR method and the method previously described [23]: 1. adult Fasciola hepatica; 2. adult Fascioloides magna; 3. Lymnaea palustris experimentally infected with F. hepatica; 4. L. palustris experimentally infected with F. magna; 5. Galba truncatula naturally infected with Haplometra cylindracea. The first five (1-5) PCR products (ITS-2) were obtained according to our described ITS-2 gene amplification method (from the left side); five others (cox-1) were obtained according to the previously used PCR protocol with primers for mitochondrial cytochromoxidase 1 [23]. 
this positive specimen was confirmed by morphology and ITS-2 sequencing [GenBank: KC248374]. All L. fuscus snails $(n=130)$ were negative.

\section{Experimental infection of snails}

In both $L$. fuscus and L. palustris no infected snail was observed in the $\geq 2-4 \mathrm{~mm}$ or $\geq 4-6 \mathrm{~mm}$ groups, and only juvenile snails (1-2 $\mathrm{mm}$ ) were infected, with respective prevalences of $13 \%$ and $51 \%$ (Table 3 ). The survival of snails 30 days $\mathrm{PE}$ in all three snail isolates was improved with increasing shell size. In both size groups of G. truncatula and in the 1-2 mm groups of both L. palustris and L. fuscus, survival rates were significantly lower in infected snails than in the negative controls (Table 2). All results from the experimental infections are summarized in Table 3 . In juvenile L. fuscus, only one snail spontaneously shed cercariae (18 metacercariae, $68^{\text {th }}$ day PE). In addition, seven snails were successfully infected but they did not produce any cercariae until dissection. In juvenile L. palustris, 17 (of 40) F. hepatica positive snails spontaneously shed cercariae from 61 days PE. Most snails in the $1-2 \mathrm{~mm}$ and $\geq 2-4 \mathrm{~mm}$ groups of G. truncatula were infected (respective prevalences, $90 \%$ and 92\%), and more than 50\% also spontaneously shed cercariae from day 43 PE. Significant differences between the stagnicoline groups and G. truncatula were noted for the spontaneous cercarial shedding, and also for metacercarial counts obtained from NCS snails, with the highest values in preadult $(\geq 2-4 \mathrm{~mm}) \mathrm{G}$. truncatula and the lowest in juvenile $L$. fuscus.

Significant positive correlations were found between shell size and the production of metacercariae in G. truncatula (1-2 mm group: $\mathrm{r}^{2}=0.54, \mathrm{p}<0.0001 ; \geq 2-4 \mathrm{~mm}$ group: $\mathrm{r}^{2}=0.28, \mathrm{p}<0.0001$ ), but not in the stagnicoline species. However, shell size at the end of the experiment was significantly $(p<0.0001)$ lower in infected snails than in the negative group for both stagnicoline species, whereas it did not differ between infected and uninfected G. truncatula (Figure 2).

The in vitro excystment rate of metacercariae obtained from NCS snails after crushing was 18\%, 23\% and 79\% for L. fuscus, L. palustris and G. truncatula, respectively.

\section{Discussion}

Evaluation of the susceptibility of potential intermediate hosts to F. hepatica infection and exploration of the epidemiological importance of Fasciola sp. snail host requires a combination of approaches, such as field screening, experimental infection of snails and taxonomic determination of species (snails, parasites) also by using the molecular methods (PCR, sequencing, BLAST). Several studies refereed on susceptibility of lymnaeid snail hosts to $F$. hepatica $[4,5,18,19,27]$, but only few publications showed combined methodology which was documented for Radix balthica and R. labiata [4]. Our study, therefore, brings the first combined approach in evaluation of vectorial capacity of European stagnicoline snails and their potential role in epidemiology of $F$. hepatica.

Although L. fuscus and L. palustris were previously considered to be low susceptible (for juveniles measuring $2 \mathrm{~mm}$ or less in height at miracidial exposure) or resistant (the older snails) to F. hepatica infection [28], both of these stagnicoline species have occasionally been listed as intermediate hosts [11,29]. In this study, we have scrutinized the stagnicoline - F. hepatica relationship both by detailed investigation of snails collected from the field and by confirmatory experimental infections, including comparison to parallel infection of the most typical intermediate host for F. hepatica in Europe, i.e. G. truncatula. In our study we compared the intramolluscan development of $F$. hepatica in the two stagnicolines with that of G. truncatula; it can be concluded that although the presence of parasite DNA in the snail bodies was confirmed, these stagnicolines must

Table 3 Infection characteristics of Lymnaea fuscus, Lymnaea palustris and Galba truncatula

\begin{tabular}{|c|c|c|c|c|}
\hline \multirow{3}{*}{$\frac{\text { Infection characteristic }}{\text { Shell size at day of exposure }(\mathrm{mm})}$} & \multicolumn{4}{|c|}{ Snail species } \\
\hline & \multirow{2}{*}{$\frac{\text { Lymnaea fuscus }}{1-2}$} & \multirow{2}{*}{$\frac{\text { Lymnaea palustris }}{1-2}$} & \multicolumn{2}{|c|}{ Galba truncatula } \\
\hline & & & $1-2$ & $\geq 2-4$ \\
\hline Prevalence of F. hepatica infection (\%) & 13.0 & 51.3 & 89.5 & 91.9 \\
\hline Number of infected snails (CS + NCS) & 9 & 40 & 51 & 68 \\
\hline Number of snails with cercarial shedding (CS)/snails without cercarial shedding (NCS) & $1 / 8$ & $17 / 23$ & $34 / 17$ & $59 / 9$ \\
\hline First observed cercarial shedding (day post exposure) & 68 & 61 & 46 & 43 \\
\hline Mean number of spontaneously shed cercariae per CS snail \pm S.D. & $18^{\mathrm{a}}$ & $18 \pm 23^{a}$ & $103 \pm 80^{b}$ & $130 \pm 102^{b}$ \\
\hline Total number of metacercariae in all CS snails & 18 & 348 & 3619 & 7952 \\
\hline Mean number of MC per NCS snail ( \pm S.D.) at dissection (after crushing) & $157 \pm 58^{\mathrm{a}}$ & $165 \pm 51^{\mathrm{a}}$ & $269 \pm 114^{b}$ & $299 \pm 88^{b}$ \\
\hline
\end{tabular}

Superscript letters $(a, b)$ indicate significant differences $(p<0.05)$ in metacercarial/cercarial production between groups.

$\mathrm{CS}$, cercariae shedding snails (spontaneous shedding of cercariae during experiment).

NCS, non cercariae shedding snails (snails that did not produce cercariae spontaneously but contained F. hepatica larvae). 
Lymnaea fuscus

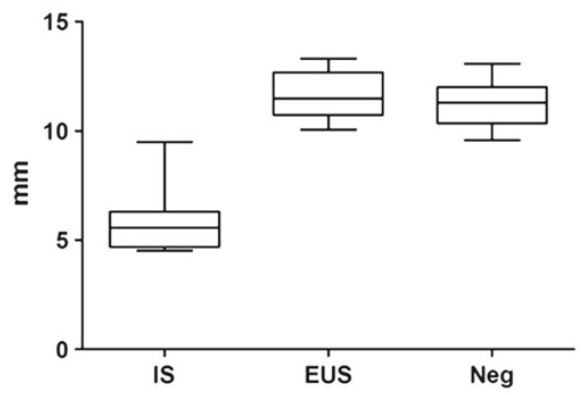

Lymnaea palustris

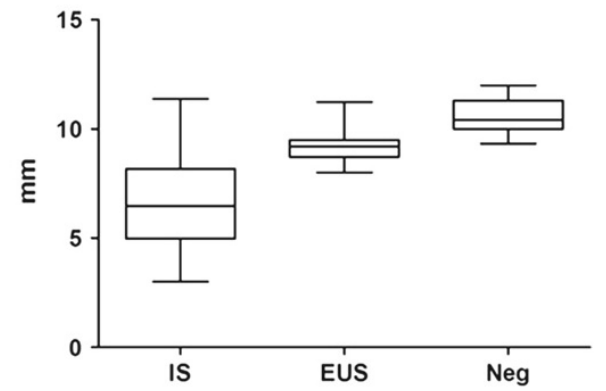

Galba truncatula

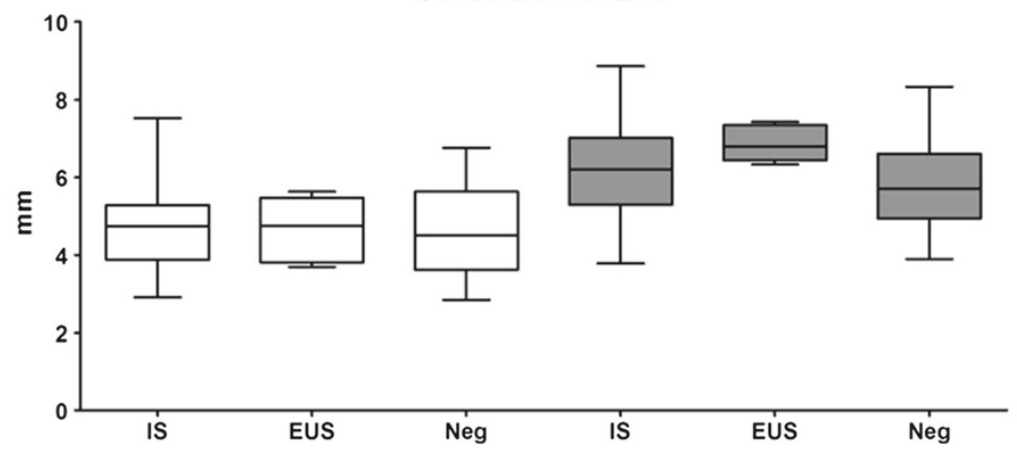

Figure 2 The effect of Fasciola hepatica infection on the size of Lymnaea fuscus, L. palustris and Galba truncatula. The data are expressed as mean shell sizes of groups 1-2 mm for L. fuscus and L. palustris (measured at day $95 \mathrm{PE}$ ) and groups 1-2 mm (white) and $\geq 2-4 \mathrm{~mm}$ (grey) for G. truncatula (measured at day 65 PE). The horizontal line inside each box represents the arithmetic mean of each group; whiskers are standard deviations. Abbreviations: IS, infected snails (cercarial shedding or no cercarial shedding); EUS, snails exposed but uninfected; Neg, negative controls.

be regarded as accidental hosts of $F$. hepatica, and their ecological role in the transmission of the parasite is probably minor. On the other hand, as it has been suggested for Radix spp. [4,5] the role of L. palustris as a vector might be more important in G. truncatula free areas.

Owing to inherent taxonomic problems with the morphological identification of stagnicoline snails $[8,11]$, molecular genetic methods have become essential to avoid confusion $[8,10,11]$. Snail conchology is not always conclusive and may sometimes result in false species identification $[10,11]$. In addition, adults of $G$. truncatula can easily be mistaken with pre-adult $L$. palustris or L. fuscus if the determination is based only on shell morphology. The agreement between ITS-2 sequences and morphological determination (length proportions of male copulatory organs and shape of bursa copulatrix) further confirms that the assessment of snail internal anatomy is an applicable method for lymnaeid species identification $[13,30]$.

Examination of $F$. hepatica in snails by dissection and morphological determination of rediae and cercariae constitute the classical screening method [3,20,31-33]. However, a PCR-based surveillance test for $F$. hepatica in snails was proposed from the 1990s [34]. When our newly applied PCR protocol based on the amplification of a specific fragment within the ITS-2 region was validated for the related F. magna [22], it showed high specificity when both DNA of adults and snails experimentally infected with $F$. magna were tested. In contrast, amplification of cox-1 [23] resulted in cross-reaction between F. hepatica and F. magna (Figure 1). These findings show that the PCR method, including those primers applied in the present study, can be used in the future as a specific diagnostic tool to distinguish between Fasciola spp. and Fascioloides.

With this PCR-based method only one snail (out of 668 L. palustris) was found to be F. hepatica positive. Although this finding is insignificant from an epidemiologic point of view, it demonstrates that $L$. palustris can be infected with $F$. hepatica under natural field conditions. However, since snails were examined only by PCR, we cannot say whether the infection was patent or not. To our knowledge, the only cases of natural infection of L. palustris with $F$. hepatica were reported from Central France [35] and also in the east of this country in a single specimen [31]. Since L. fuscus was found only at one farm and the total number of examined snails was lower 
than that of $L$. palustris, we cannot fully exclude natural infection of this species elsewhere.

Data from the experimental study clearly show that both $L$. palustris and $L$. fuscus are susceptible to F. hepatica and that the parasite can complete its development in both species. However, in comparison to G. truncatula these stagnicoline snails were harder to infect and there was also clear evidence of age resistance. Lower survival of infected snails, when compared to that noted in the negative control groups, coincides with reports on this or various other trematode and snail species [21,36-38]. Increased parasite-induced mortality in juvenile snails infected with trematodes is common [39], and is usually related to i) mechanical alteration of tissues by penetration of miracidia and/or ii) the growth and migration of firstgeneration rediae (mother rediae) [40]. Suppressive effect of trematode infection on immune system, nutrition of juvenile snails and general snail fitness is also known in other snail species [41]. This effect of snail survival was, moreover, supported by the fact that survival rates between the exposed and negative groups did not vary in older categories of $L$. palustris and L. fuscus $(\geq 2-4 \mathrm{~mm}, \geq$ 4-6 $\mathrm{mm}$ ), where snails were exposed but remained uninfected.

The absence of $F$. hepatica infection in both stagnicoline snails with shell size greater than $2 \mathrm{~mm}$ at exposure and high prevalence in both age groups of G. truncatula suggest that $2 \mathrm{~mm}$ constitutes the onset of age resistance in $L$. palustris and L. fuscus to $F$. hepatica. The age resistance in snails has already been reported for L. palustris $[9,42]$ and L. fuscus [19,21], and it is, therefore, legitimately considered as one of the important markers of snail susceptibility to $F$. hepatica infection [9]. A possible explanation for age resistance might be related to the development of immune mechanisms during the first days after snail hatching, as has been documented earlier in L. palustris [42]. Thus, natural resistance of $L$. palustris against $F$. hepatica was explained by the fact that miracidia are able to penetrate into the snail body but forming sporocysts are immediately encapsulated and removed by the snail defense mechanisms [42]. Our results almost coincide with those of prior studies [28,42], but it seems that development of the snail immune mechanism may last up to 14 days according to our observations.

Metacercarial production and the time of first cercarial shedding uncover important details about the snail-trematode interaction. Whilst the highest reported metacercarial production in G. truncatula was 1789 metacercariae in a snail exposed to 5 miracidia [43], the average metacercarial production under experimental conditions was 154 per snail after spontaneous shedding, and 344 after dissection 55 days post exposure (at $20^{\circ} \mathrm{C}$ ) [44]. This is in agreement with the values obtained for G. truncatula in the present study. In both stagnicoline species, metacercarial production was significantly lower and also more delayed than in G. truncatula. This suggests that despite the successful differentiation of cercariae, the larval development process was obviously delayed. Furthermore, only a few specimens of L. palustris and a single $L$. fuscus shed cercariae spontaneously. Most cercariae from $L$. fuscus and $L$. palustris encysted in the Petri dish mainly at dissection (day $95 \mathrm{PE}$ ), and with an average production of 157-168 metacercariae per infected snail. This is in agreement with the very low spontaneous cercarial production observed in accidental intermediate hosts of $F$. magna, and also when fully differentiated cercariae were found at dissection [21]. This phenomenon is difficult to explain. Nevertheless, as in the current study, it reflects the fact that the studied snail-trematode interactions were suboptimal.

The effect of $F$. hepatica infection on snail growth is a frequently studied variable concerning snail-trematode interactions. Compared to the shell height of negative controls, a significantly reduced size (stunting) of infected snails was noted for both stagnicoline species. Furthermore, as no difference in growth between infected and uninfected G. truncatula was observed, this contradicts the 'parasitic gigantism' hypothesis observed in lymnaeid snails [45]. Although other studies observed increased growth in F. hepatica-infected G. truncatula when compared to uninfected controls [46,47], an inverse effect on shell size has been shown in other lymnaeids such as L. palustris [18], L. fuscus [19], L. stagnalis [18] and Pseudosuccinea columella [48]. As we already have suggested for F. magna [21], this reduction effect on growth in lymnaeids other than G. truncatula probably indicates the level of co-evolution, which gradually will happen when the parasite and snail live in close ecological interaction with one another. Obviously, this controversy in growth effect caused by $F$. hepatica needs further research. Interestingly, cercarial/metacercarial production in our study positively correlated with shell size of G. truncatula but not with that of stagnicoline snails. The dependency of cercariae amounts on snail volume has been reported in G. truncatula as well as in other lymnaeid species $[49,50]$.

\section{Conclusions}

From field investigations and experimental infections of snails, it is clear that both L. fuscus and L. palustris can sustain larval development of $F$. hepatica but with an apparent level of age resistance. Nevertheless, when all infection characteristics in both stagnicolines are compared, it was evident that $L$. palustris is better suited as an intermediate host, and thus more suitable as a vector of $F$. hepatica in Sweden than is L. fuscus. This is further supported by the finding of a naturally infected $L$. palustris in the field. In fact, the present finding represents the first case where species 
identification of both the stagnicoline snail and its parasite was confirmed by a molecular method and sequencing. Spontaneous cercarial shedding, viability of metacercariae in L. palustris, together with a high level of amphibiousity in its natural habitats make this species likely as an intermediate host of F. hepatica in Sweden, along with G. truncatula. However, because of age resistance, the role of L. palustris in transmission of the trematode in natural habitats is likely to be much lower than for G. truncatula. Further, the existence of 'parasitic gigantism' was doubted in this study. Thus, we believe that the effect on snail growth may be related to co-adaptation/co-evolution of the trematode and snail.

\section{Endnotes}

${ }^{\text {a}}$ These taxonomic names are used throughout the text and the term 'stagnicoline' to describe all species with a similar shell morphology, including Lymnaea palustris, L. fuscus, L. corvus, and Catascopia terebra.

\section{Competing interests}

The authors declare that they have no competing interests.

\section{Authors' contributions}

AN designed the study, participated in field collections, performed all laboratory work and wrote main parts of the manuscript. MK helped with writing of the manuscript and participated in molecular identification of snail species. LB carried out morphological identification of snails. DR helped with designing of experimental infections and made comments to the manuscript. JH conceived the study and attracted the funding, as well as contributed to the interpretation of the data and writing of the manuscript. All authors have read and approved the final manuscript.

\section{Acknowledgements}

This study was supported by the Swedish Foundation for Agricultural Research (contract No. H1050003), the 7th framework programme of the EU (GLOWORM, Project FP7-KBBE-2012-288975) and the Charles University in Prague (UNCE 204017, PRVOUK P41, SW 267210/2013). We thank Annie Engström and Sofia Sollenberg (BVF, SLU, Uppsala) for their help with DNA isolation and sequencing, and help during experimental infections of snails. We are grateful for cooperation with the Swedish Animal Health Service (namely Katarina Gustafsson, Ulrika König, Virpi Welling and Helen B. Averpil). The authors thank David A. Morrison for revising the English text.

\section{Author details}

'Department of Biomedical Sciences and Veterinary Public Health, Section for Parasitology, Swedish University of Agricultural Sciences (SLU), Uppsala 750 07, Sweden. ${ }^{2}$ Department of Parasitology, Faculty of Science, Charles University, Viničná 7, Prague 2128 44, Czech Republic. ${ }^{3}$ Department of Botany and Zoology, Faculty of Science, Masaryk University, Kotlářská 2, Brno 611 37, Czech Republic. ${ }^{4}$ Agency for Nature Conservation and Landscape Protection of the Czech Republic, Kokořínsko Protected Landscape Area Administration, Česká 149, Mělník 276 01, Czech Republic. ${ }^{5}$ INSERM U 1094, Faculty of Medicine and Faculty of Pharmacy, 2 rue du Docteur Raymond Marcland, Limoges 87025, France.

Received: 4 June 2013 Accepted: 26 August 2013

Published: 29 August 2013

\section{References}

1. Andrews SJ: Life cycle of Fasciola hepatica. In Fasciolosis. Edited by Dalton JP. Oxon: CABI Publishing; 1999:1-29.

2. Mas-Coma S, Valero MA, Bargues MD: Fasciola, lymnaeids and human fascioliasis, with a global overview on disease transmission, epidemiology, evolutionary genetics, molecular epidemiology and control. Adv Parasitol 2009, 69:41-146.
3. Dreyfuss G, Novobilský A, Vignoles P, Bellet V, Koudela B, Rondelaud D: Prevalence and intensity of infections in the lymnaeid snail Omphiscola glabra experimentally infected with Fasciola hepatica, Fascioloides magna and Paramphistomum daubneyi. J Helminthol 2007, 81:7-12.

4. Caron Y, Lasri S, Losson B: Fasciola hepatica: An assessment on the vectorial capacity of Radix labiata and $R$. balthica commonly found in Belgium. Vet Parasitol 2007, 149:95-103.

5. Relf V, Good B, McCarthy E, De-Waal T: Evidence of Fasciola hepatica infection in Radix peregra and a mollusc of the family Succineidae in Ireland. Vet Parasitol 2009, 163:152-155.

6. Nielsen K: Fascioliasis, a general presentation. Nord Vet Med 1974, 26:9-12.

7. Vinarski MV: One, two, or several? How many lymnaeid genera are there? Ruthenica 2013, 23:41-58.

8. Bargues MD, Horak P, Patzner RA, Pointier JP, Jackiewicz M, Meier-Brook C, Mas-Coma S: Insights into the relationships of Palearctic and Nearctic lymnaeids (Mollusca: Gastropoda) by rDNA ITS-2 sequencing and phylogeny of stagnicoline intermediate host species of Fasciola hepatica. Parasite 2003, 10:243-255.

9. Boray JC: Studies on relative susceptibility of some lymnaeids to infection with Fasciola hepatica and F. gigantica and on adaptation of Fasciola spp. Ann Trop Med Parasitol 1966, 60:114-124.

10. Correa AC, Escobar JS, Durand P, Renaud F, David P, Jarne P, Pointier JP, Hurtrez-Boussès $S$ : Bridging gaps in the molecular phylogeny of the Lymnaeidae (Gastropoda: Pulmonata), vectors of fascioliasis. BMC Evol Biol 2010, 10:381.

11. Bargues MD, Vigo M, Horak P, Dvorak J, Patzner RA, Pointier JP, Jackiewicz M, Meier-Brook C, Mas-Coma S: European Lymnaeidae (Mollusca: Gastropoda), intermediate hosts of trematodiases, based on nuclear ribosomal DNA ITS-2 sequences. Infect Genet Evol 2001, 1:85-107.

12. Jackiewicz M: Błotniarki Europy (Gastropoda: Pulmonata: Lymnaeidae) Poznan: Wydawnictwo Kontekst; 2000.

13. Glöer P: Die Süßwassergastropoden Nord- und Mitteleuropas. Hackenheim: Conchbooks; 2002

14. Vinarski M, Glöer P: Taxonomic notes on Euro-Siberian freshwater molluscs. 3. Galba occulta Jackiewicz, 1959 is junior synonym of Limnaea palustris var. terebra Westerlund 1885. Mollusca 2008, 26:175-185.

15. Meier-Brook C, Bargues MD: Catascopia, a new genus for three Nearctic and one Palearctic stagnicoline species (Gastropoda: Lymnaeidae). Folia Malacologica 2002, 10:83-84.

16. Nilsson C, Ericsson U, Medin M, Sundberg I: Sötvattenssnäckor i södra Sverige - en jämförelse med 1940-talet. Stockholm: Naturvårdsverket; 1998.

17. Hubendick B: Recent Lymnaeidae, their variation, morphology, taxonomy, nomenclature, and distribution. Stockholm: Almqvist \& Wiksell; 1951.

18. Kendall SB: Snail hosts of Fasciola hepatica in Britain. J Helminthol 1950, 24:63-74.

19. Dreyfuss G, Abrous M, Rondelaud D: The susceptibility of Lymnaea fuscus to experimental infection with Fasciola hepatica. J Parasitol 2000, 86:158-160.

20. Malone JB, Loyacano AF, Hugh-Jones ME, Corkum KC: A 3-year study on seasonal transmission and control of Fasciola hepatica of cattle in Louisiana. Prev Vet Med 1984, 3:131-141.

21. Novobilský A, Kašný M, Pankrác J, Rondelaud D, Engström A, Höglund J: Lymnaea fuscus (Pfeiffer, 1821) as a potential intermediate host of Fascioloides magna in Europe. Exp Parasitol 2012, 132:282-286.

22. Králová-Hromadová I, Špakulová M, Horáčková E, Turčeková L, Novobilský A, Beck R, Koudela B, Marinculic A, Rajský D, Pybus M: Sequence analysis of ribosomal and mitochondrial genes of the giant liver fluke Fascioloides magna (Trematoda: Fasciolidae): intraspecific variation and differentiation from Fasciola hepatica. J Parasitol 2008, 94:58-67.

23. Cucher MA, Carnevale S, Prepelitchi L, Labbe JH, Wisnivesky-Colli C: PCR diagnosis of Fasciola hepatica in field-collected Lymnaea columella and Lymnaea viatrix snails. Vet Parasitol 2006, 137:74-82.

24. Sanabria R, Mouzet R, Pankrác J, Djuikwo Teukeng FF, Courtioux B, Novobilský A, Höglund J, Kašný M, Vignoles P, Dreyfuss G, et al: Lymnaea neotropica and Lymnaea viatrix, potential intermediate hosts for Fascioloides magna. J Helminthol. in press. http://dx.doi.org/10.1017/S0022149X12000582.

25. Wikerhauser T: A rapid method for determining the viability of Fasciola hepatica metacercariae. Am J Vet Res 1960, 21:895-897.

26. Glöer P, Meier-Brook C: Süsswassermollusken. In Bestimmungsschlüssel für die Bundesrepublik Deutschland. Hamburg, Germany: Deutscher Jugendbund für Naturbeobachtung; 1998. 
27. Cruz-Reyes A, Malek EA: Suitability of six lymnaeid snails for infection with Fasciola hepatica. Vet Parasitol 1987, 24:203-210.

28. Boray JC: Potential impact of exotic Lymnaea spp on fascioliasis in Australasia. Vet Parasitol 1978, 4:127-141.

29. Correa AC, Escobar JS, Noya O, Velasquez LE, Gonzalez-Ramirez C, HurtrezBoussès S, Pointier JP: Morphological and molecular characterization of Neotropic Lymnaeidae (Gastropoda: Lymnaeoidea), vectors of fasciolosis. Infect Genet Evol 2011, 11:1978-1988.

30. Beran L: Aquatic molluscs of the Czech Republic - distribution and its changes, habitats, dispersal, threat and protection, Red List. Uherské Hradiště: Sborník prírodovědného klubu; 2002.

31. Degueurce F, Abrous M, Dreyfuss G, Rondelaud D, Gevrey J: Paramphistomum daubneyi and Fasciola hepatica: the prevalence of natural or experimental infections in four species of freshwater snails in eastern France. J Helminthol 1999, 73:197-202

32. Dreyfuss G, Vignoles P, Rondelaud D: Natural infections of Omphiscola glabra (Lymnaeidae) with Fasciola hepatica in central France. Parasitol Res 2003, 91:458-461.

33. Manga-Gonzalez Y, Gonzalez-Lanza C, Otero-Merino CB: Natural infection of Lymnaea truncatula by the liver fluke Fasciola hepatica in the Porma Basin, Leon, NW Spain. J Helminthol 1991, 65:15-27.

34. Kaplan RM, Dame JB, Reddy GR, Courtney CH: A repetitive DNA-probe for the sensitive detection of Fasciola hepatica infected snails. Int J Parasitol 1995, 25:601-610.

35. Dreyfuss G, Moukrim A, Rondelaud D, Vareille-Morel C: Field observations concerning infection of Lymnaea palustris by Fasciola hepatica. J Helminthol 1994, 68:115-118.

36. Gutiérrez A, Perera G, Yong M, Sánchez J, Wong L: Life-history traits of Fossaria cubensis (Gastropoda: Lymnaeidae) under experimental exposure to Fasciola hepatica (Trematoda: Digenea). Mem Inst Oswaldo Cruz 2000, 95:747-752.

37. Gutiérrez A, Yong M, Perera G, Sánchez J, Théron A: Fasciola hepatica (Trematoda: Digenea): its effect on the life history traits of Pseudosuccinea columella (Gastropoda: Lymnaeidae), an uncommon interaction. Parasitol Res 2002, 88:535-539.

38. Sorensen RE, Minchella DJ: Snail-trematode life history interactions: past trends and future directions. Parasitology 2001, 123:S3-S18.

39. Meier M, Meier-Brook C: Schistosoma mansoni: effect on growth, fertility, and development of distal male organs in Biomphalaria glabrata exposed to miracidia at different ages. Z Parasitenkd 1981 66:121-131.

40. Erhardová-Kotrlá B: The occurrence of Fascioloides magna (Bassi, 1875) in Czechoslovakia. Prague: Academia; 1971.

41. Adema CM, Loker ES: Specificity and immunobiology of larval Digeneansnail associations. In Advances in trematode biology. Edited by Fried B, Graczyk TK. New York: CRC Press; 1997:229-263.

42. McReath AM, Reader TAJ, Southgate VR: The development of the hostresponse in juvenile Lymnaea palustris to invasion by Fasciola hepatica. $Z$ Parasitenkd 1982, 67:175-184

43. Hodasi JKM: Output of cercariae of Fasciola hepatica by Lymnaea truncatula and distribution of metacercariae on grass. Parasitology 1972, 64:53-60.

44. Rondelaud D, Mouzet R, Vignoles P, Dreyfuss G, Cabaret J: The production of mammalian trematode infective stages by the snail Galba truncatula. J Helminthol. in press, http://dx.doi.org/10.1017/S0022149X1200082X

45. Thompson SN: Physiology and biochemistry of snail-larval trematode relationship. In Advances in trematode biology. Edited by Fried B, Graczyk TK. New York: CRC Press; 1997:149-195.

46. Wilson RA, Denison J: Parasitic castration and gigantism of Lymnaea truncatula infected with the larval stages of Fasciola hepatica. $Z$ Parasitenkd 1980, 61:109-119.

47. Chapuis E: Correlation between parasite prevalence and adult size in a trematode-mollusc system: evidence for evolutionary gigantism in the freshwater snail Galba truncatula? J Mollus Stud 2009, 75:391-396

48. Salazar L, Estrada VE, Velasquez LE: Effect of the exposure to Fasciola hepatica (Trematoda: Digenea) on life history traits of Lymnaea cousini and Lymnaea columella (Gastropoda: Lymnaeidae). Exp Parasitol 2006, 114:77-83.
49. Rondelaud D, Novobilský A, Höglund J, Kašný M, Pankrác J, Vignoles P, Dreyfuss $G$ : Growth rate of the intermediate snail host Galba truncatula influences redial development of the trematode Fascioloides magna. J Helminthol. in press, http://dx.doi.org/10.1017/S0022149X13000370.

50. Rondelaud D, Barthe D: Fasciola hepatica L.: the relationship between the productivity of a single sporocyst and the size of Lymnaea truncatula Müller. Z Parasitenkd 1987, 74:155-160.

doi:10.1186/1756-3305-6-25

Cite this article as: Novobilský et al: Lymnaea palustris and Lymnaea fuscus are potential but uncommon intermediate hosts of Fasciola hepatica in Sweden. Parasites \& Vectors 2013 6:251

\section{Submit your next manuscript to BioMed Central and take full advantage of:}

- Convenient online submission

- Thorough peer review

- No space constraints or color figure charges

- Immediate publication on acceptance

- Inclusion in PubMed, CAS, Scopus and Google Scholar

- Research which is freely available for redistribution 